\title{
Haplotypes and DNA sequence variation within and surrounding the transthyretin gene: genotype-phenotype correlations in familial amyloid polyneuropathy (V30M) in Portugal and Sweden
}

\author{
Miguel Luz Soares ${ }^{1,2}$, Teresa Coelho ${ }^{3,4}$, Alda Sousa ${ }^{5,6}$, Gösta Holmgren ${ }^{7}$, \\ Maria João Saraiva ${ }^{2,5}$, Daniel L Kastner ${ }^{8}$ and Joel N Buxbaum*,1
}

\begin{abstract}
${ }^{1}$ Division of Rheumatology Research and the W. M. Keck Autoimmune Disease Center, Department of Molecular and Experimental Medicine, The Scripps Research Institute, La Jolla, CA, USA; ${ }^{2}$ Amyloid Unit, Instituto de Biologia Molecular e Celular (IBMC), Porto, Portugal; ${ }^{3}$ Centro de Estudos de Paramiloidose, Porto, Portugal;

${ }^{4}$ Neuropsychophysiology Unit, IBMC, Porto, Portugal; ${ }^{5}$ Instituto de Ciências Biomédicas Abel Salazar, Porto, Portugal; ${ }^{6}$ UnIGENe, IBMC, Porto, Portugal; ${ }^{7}$ Department of Clinical Genetics, University of Umea, Sweden; ${ }^{8}$ Genetics and Genomics Branch, National Institute of Arthritis and Musculoskeletal and Skin Diseases, Bethesda, MD, USA
\end{abstract}

Familial amyloid polyneuropathy (FAP) is a lethal autosomal dominant disorder in which fibrils derived from mutant forms of transthyretin (TTR), the normal plasma carrier of thyroxine $\left(T_{4}\right)$ and retinol-binding protein, are deposited in tissues. Over 80 TTR sequence variants are associated with FAP, but the aminoacid substitutions alone do not completely explain the variability in disease penetrance, pathology and clinical course. To analyze the factors possibly contributing to this phenotypic variability, we characterized the variations within the wild-type and mutant (Val30Met) TTR genes and their flanking sequences by performing extended microsatellite haplotype analyses, sequencing and single-nucleotide polymorphism haplotyping of genomic DNA from Portuguese and Swedish carriers of V30M. We identified 10 new polymorphisms in the TTR untranslated regions, eight resulting from single-base substitutions and two arising from insertion/deletions in dinucleotide repeat sequences. The data suggest that the onset of symptoms of FAP V30M may be modulated by an interval downstream of TTR on the accompanying noncarrier chromosome (defined by microsatellites $D 185457$ and $D 18 S 456$ ), but not by the immediately $5^{\prime}$ - and 3'-flanking sequences of TTR. During the course of these studies, we also encountered the first instance in which the previously described intragenic haplotype III may be associated with V30M FAP in the Portuguese population.

European Journal of Human Genetics (2004) 12, 225-237. doi:10.1038/sj.ejhg.5201095

Published online 19 November 2003

Keywords: transthyretin; familial amyloid polyneuropathy; V30M mutation; haplotypes; phenotypic heterogeneity; disease onset

\footnotetext{
*Correspondence: Dr Joel N Buxbaum, Department of Molecular and Experimental Medicine, The Scripps Research Institute, 10550 North Torrey Pines Road, MEM-230, La Jolla, CA 92037, USA.

Tel.: + 1 (858) 784 8885; Fax: + 1 (858) 784 8891;

E-mail: jbux@scripps.edu

TTR accession numbers: GenBank M11518; GDB 119471; MIM 176300. Received 7 March 2003; revised 1 August 2003; accepted 8 August 2003
}

Introduction

Missense single-nucleotide substitutions in the transthyretin (TTR) gene define autosomal dominant lethal hereditary types of systemic amyloidosis characterized by the extracellular deposition of protein fibrils as amyloid (ATTR) (MIM 176300). In Europe and Asia, autosomal dominant 
familial amyloid polyneuropathy (FAP), with peripheral sensorimotor, autonomic neuropathy and cardiomyopathy, is the most common syndrome. ${ }^{1}$ The most frequent mutation associated with FAP - V30M - is highly prevalent in Portugal, but is also found in Sweden, Japan, Spain, Italy, France, the United States and other countries. FAP V30M penetrance and age of disease onset vary among and within populations. In Portugal, the penetrance is high (at least $80 \%$ ) and symptoms typically develop before the age of 40 years. $^{2}$ Subsets of families with late-onset patients and aged asymptomatic carriers have also been identified. ${ }^{3,4}$ Some kindreds display genetic anticipation, that is, progressively earlier onset and more severe disease in the succeeding generations. ${ }^{5}$ Anticipation in many neurodegenerative diseases has been related to the expansion of trinucleotide repeats in specific genes; however, this form of dynamic mutation does not appear to be the case in Portuguese FAP. ${ }^{6}$

Swedish carriers of TTR V30M display lower penetrance (approximately 5\%) and later onset, with symptoms usually developing after age 50 years. ${ }^{7,8}$ Disease onset in Japanese patients may be early or late. ${ }^{9}$

The first approach to genetic variation in FAP V30M involved the characterization of intragenic haplotypes defined by six intronic single-nucleotide polymorphisms (SNPs). ${ }^{10,11}$ The distribution of haplotypes associated with V30M disease in various populations has been established, and is not consistent with genetic drift arising from one ancient founder. ${ }^{10-12}$ Although some of the five haplotypes identified (out of 64 possible arrangements; named I-V) could have arisen by simple recombination events, others (e.g. haplotype III) would require complex crossovers and multiple recombinations within several hundred base pairs, or interchromosomal gene conversion, both statistically less likely than the occurrence of multiple founders, especially in view of the fact that the site, a CpG dinucleotide, constitutes a mutational hotspot. $^{13,14}$

In Portugal and Sweden, only haplotype I had previously been found associated with the mutation. The second most common haplotype - III - segregates with V30M in French, Italian, British and Japanese kindreds. Thus, the evidence for recurring mutation is strong and descent from a single founder could only be explained by a rare combination of events. However, a single founder could be responsible for all of the cases in the Portuguese and Swedish populations. These conclusions have been based on analyses restricted to the exon and intervening intronic sequences and limited to a few markers. There are no data regarding genetic variation in regulatory sequences that might influence the clinical phenotype. Most importantly, the establishment of genotype-phenotype correlations, namely a genetic basis for the variability in clinical presentation and age of onset, if present in the vicinity of the gene, but not within it, is difficult.
To overcome these limitations and further characterize genetic variation within and around the TTR gene, we performed nucleotide sequence analysis and extended haplotyping in Portuguese patients with variable disease onset, and Swedish subjects.

\section{Material and methods Subjects and DNA samples}

The present study included 127 FAP families with a total of 191 individuals (170 carriers and 21 noncarriers), and 92 control subjects (Table 1 ). Of the V30M carriers, 140 were affected and 30 were asymptomatic. The term Familial is used to identify individuals from families with several members studied here; the term Singleton refers to single representatives of distinct FAP families. The male-to-female ratio among the 152 Portuguese subjects was 1:1 (78 men and 74 women). Of the affected individuals, 61 were men and 61 were women, with a sex ratio of $1: 1$, while the 30 asymptomatic carriers showed a male-to-female ratio of 1.3:1. Among the Swedes, the sex ratio was $1.5: 1$ in the 18 patients. All individuals referred to as carriers, whether affected or not, had the TTR V30M as assessed by a restriction essay described elsewhere. ${ }^{15}$ The affected subjects had been diagnosed with FAP, according to the presence of characteristic clinical features of the disorder. ${ }^{1}$ In all, 58 Portuguese and 34 Swedish unrelated individuals, who did not carry the V30M mutation, served as controls. Blood samples were obtained with informed consent and DNA was extracted by standard techniques.

\section{Age of onset}

Among the 122 affected carriers from Portugal, the age of onset was known for 113 patients and averaged $41.4 \pm 14.4$ (SD) years, ranging from 21 to 80 years. In the classical onset subset (below age $40, n=71$ ), the mean age of onset was $31.3 \pm 4.6$ years, whereas the late-onset subset (above age $50, n=39$ ) presented an average onset of $59.5 \pm 6.6$ years. Of the 30 asymptomatic carriers, 18 were above 50 years of age at the time of the study, ranging from 53 to 82 years with an average of $66.6 \pm 10.8$ years. Eight V30M carriers were asymptomatic over 70 years of age. All the Swedish patients were of late onset (above 50 years).

\section{Genomic DNA sequencing}

Genomic DNA from 10 Portuguese V30M carriers, five with onset at ages 22-24 years (early onset), three with onset between ages 63 and 72 years (late onset), and two asymptomatic carriers aged 71 and 72 years at the time the study was initiated (classified as late onset) was sequenced. A Portuguese noncarrier was used for the $3^{\prime}$ UTR portion of the target interval. A region of $19888 \mathrm{bp}$ (comprising the $7620 \mathrm{bp}$ of TTR complete cds (GenBank M11518), plus 6,559 bp upstream (5' UTR) and $5709 \mathrm{bp}$ downstream (3' UTR)) was amplified from each genomic 
Table 1 Study subjects

\begin{tabular}{|c|c|c|c|c|}
\hline Population & Mutation status & Disease status & Type* & Disease status \\
\hline \multirow{7}{*}{ Portuguese } & \multirow{4}{*}{152 carriers } & & \multirow{3}{*}{54 familial } & \\
\hline & & 122 affected & & 23 asymptomatic \\
\hline & & 30 asymptomatic & & \\
\hline & & & & 91 affected \\
\hline & \multirow{3}{*}{78 noncarriers } & & 98 singletons & 7 asymptomatic \\
\hline & & & 20 familial & \\
\hline & & & & \\
\hline \multirow{4}{*}{ Swedish } & \multirow{2}{*}{18 carriers } & \multirow{2}{*}{ All affected } & 9 familial & \\
\hline & & & 9 singletons & \\
\hline & \multirow[b]{2}{*}{35 noncarriers } & & 1 familial & \\
\hline & & & 34 controls & \\
\hline
\end{tabular}

${ }^{*}$ As described in Material and Methods.

DNA sample in 45 overlapping segments and sequenced using the same primers employed for PCR amplification (Table 2a).

PCR amplification was performed in a MWG Biotech Primus $96 \mathrm{HPL}$ thermal cycler with AmpliTaq Gold (PE Applied Biosystems, Foster City, CA, USA) in 25- $\mu$ l reactions containing $10-50 \mathrm{ng}$ of genomic DNA. The samples were denatured at $96^{\circ} \mathrm{C}$ for $6 \mathrm{~min}$ and cycled 35 times with denaturation at $94^{\circ} \mathrm{C}$ for $30 \mathrm{~s}$, annealing at temperatures specified above for $30 \mathrm{~s}$ and extension at $72^{\circ} \mathrm{C}$ for $30 \mathrm{~s}$, followed by a final extension at $72^{\circ} \mathrm{C}$ for $10 \mathrm{~min}$. Following column purification with a PCR-purification kit (Qiagen, Valencia, CA, USA), sequencing of both strands was performed with dye terminator chemistry (PE Applied Biosystems) according to the manufacturer's instructions. Sequencing reactions were electrophoresed on an ABI Prism 377 Sequencer (PE Applied Biosystems); data were analyzed with Sequencher 3.0 (Gene Codes, Ann Arbor, MI, USA).

\section{Microsatellite analysis}

The microsatellite study included 18 Portuguese families with 54 V30M carriers and 20 noncarriers, three Swedish kindreds with nine carriers and one noncarrier, 17 singletons (eight Portuguese and nine Swedes) and six Portuguese controls. Of the Portuguese kindreds, eight had classical onset, six late onset and four exhibited anticipation; six Portuguese singletons had classical onset and the remaining two had late onset. The Swedish subjects, either familial or singletons, had late onset.

Genotyping in the chromosomal region of TTR on proximal $18 \mathrm{q}$ was performed with markers D18S457 (GDB:239675), D18S456 (GDB:239623) and D18S1133
(GDB:659622) (centromere to telomere). The Genebridge 4 (GB4) map (The International RH Mapping Consortium) places the TTR gene immediately centromeric of a $2 \mathrm{cM}$ interval defined by D18S457 (microsatellite anchor marker $A F M 238 v b 6$ ) and D18S456 (microsatellite anchor marker AFM234zb6). This interval is located approximately $700 \mathrm{~kb}$ downstream of $T T R$ cds and spans $1.3 \mathrm{Mb}$. Marker D18S1133, telomeric to D18S456, was used to facilitate the inference of linkage phase. Genotyping for D18S457, D18S456 and D18S1133 was performed using the PCR conditions and oligonucleotide primers available through the Genome database. Additionally, we designed primers to amplify two CA-repeat elements previously identified in TTR $5^{\prime} \mathrm{UTR}^{16}{ }^{16}$ in order to determine if the sites were polymorphic and could be used as microsatellite markers (Table 2b). All primers were assembled using standard fluorophore chemistry (PE Applied Biosystems); amplification was followed by electrophoresis on an ABI Prism 377 DNA Sequencer with the GeneScan 3.1 software (PE Applied Biosystems). The data were analyzed with Genotyper 2.5 , and haplotypes were constructed minimizing the number of intrafamilial recombinations. For each pedigree, the parental alleles associated with V30M were determined and counted only once.

\section{SNP analysis}

Four of the eight SNPs identified by genomic sequencing in TTR flanking regions were characterized in $117 \mathrm{~V} 30 \mathrm{M}$ carriers and 87 controls. In all, 97 Portuguese carriers (90 affected, seven asymptomatic) were separated into two classes according to the age of onset: 58 had classical onset (below age 40 years) and 39 had late onset (above age 50 years). The asymptomatic subjects were included in the 
Table 2 Primers employed for PCR amplification and cycle sequencing

\begin{tabular}{|c|c|c|c|c|}
\hline & Upstream primer ( $5^{\prime}$ to $\left.3^{\prime}\right)$ & Downstream primer $\left(5^{\prime}\right.$ to $\left.3^{\prime}\right)$ & Annealing temp. & Fragment size (bp) \\
\hline \multicolumn{5}{|c|}{$\begin{array}{l}\text { (A) Genomic DNA sequencing } \\
5^{\prime} \text { UTR }\end{array}$} \\
\hline i & ТСТСАССТСТТСАСАGАСАGС & CCATGGAATGCTATGCAGAA & $60^{\circ} \mathrm{C}$ & 486 \\
\hline ii & TTССААСТССАТССАТGTCC & TGCTCAACATCACTGGTCCT & $64^{\circ} \mathrm{C}$ & 473 \\
\hline iii & TAGCCATTCTGACAGGTGTG & ССАААСАСАТССТТССGАТА & $60^{\circ} \mathrm{C}$ & 477 \\
\hline iv & TGACACATACCCСAATGCAG & CСATGTCTTGGTCCAGGTTC & $60^{\circ} \mathrm{C}$ & 463 \\
\hline $\mathrm{v}$ & TGTTTATGGATAAAATCTTCTAACACG & TGCAGGAGAGCCTAGGAAAG & $60^{\circ} \mathrm{C}$ & 547 \\
\hline vi & TATTCAACAATGGCGGAGGA & ATTTTCTGAGGGTGCCTGTC & $60^{\circ} \mathrm{C}$ & 499 \\
\hline vii & TGGGCATTTCAGTATCAACAG & GAAGGTCTTCCTITCCTGTGTTT & $60^{\circ} \mathrm{C}$ & 531 \\
\hline viii & TGTGGTGACCATTGACCCTA & СССАТТСТССАТСАТСТССТ & $58^{\circ} \mathrm{C}, \mathrm{D}$ & 519 \\
\hline ix & ACAGGCATGCAATGTGAAAT & СССАGТСТСАGGСАGТTСТT & $64^{\circ} \mathrm{C}$ & 494 \\
\hline$x$ & GGCATGGCCTGAAAACTGT & АСССАAАTATGGGACССТGT & $60^{\circ} \mathrm{C}$ & 515 \\
\hline xi & GTGGGGACACAAAGCCTAAC & ATTGCTGGTCTTCCAACAGC & $58^{\circ} \mathrm{C}, \mathrm{D}$ & 501 \\
\hline xii & TCGGGATGCTGAGGATCTTA & GTTTCAGCACTGCACCCTGT & $60^{\circ} \mathrm{C}$ & 526 \\
\hline xiii & AGACTCTGTGCAGCCCAAAT & CATTCGATCCСAGTTCTGCT & $60^{\circ} \mathrm{C}$ & 511 \\
\hline xiv & CAAACGAGTTGGCCGAGTAT & ACTAGCATGCGTGGCTTTGT & $60^{\circ} \mathrm{C}$ & 501 \\
\hline$x \mathrm{~V}$ & GCTCTTGGCTTGTATTTGTCC & СТССТGАGСТСААGСААТСС & $60^{\circ} \mathrm{C}$ & 510 \\
\hline$x v i$ & ATGCCCAATGCAGAAGAGTC & AAGGAAAAACCCTTGGCAGT & $60^{\circ} \mathrm{C}$ & 508 \\
\hline \multicolumn{5}{|c|}{ TTR cds } \\
\hline $\mathrm{i}$ & ТTССАААTGАСТTAGTTTGGСTA & СТGССААТСТGАСТGСАААС & $58^{\circ} \mathrm{C}, \mathrm{D}$ & 517 \\
\hline ii & GGGTTACTTATTCTCTCTTTGTTGA & CCAAATACATTTTATGGAGGGATA & $60^{\circ} \mathrm{C}, 1$ & 570 \\
\hline iii & GGTGCATTAGGTTTGTAATATCTGG & TGATCCCATTATCAGGAACG & $60^{\circ} \mathrm{C}$ & 605 \\
\hline iv & TCTGGAGGCAGAAACCATTC & GAGGAGAGGAGTTCTGATTCCTT & $60^{\circ} \mathrm{C}, 2$ & 586 \\
\hline $\mathrm{v}$ & TGAAGGATGCCСТСTITTTG & TGCAGGTAGAAAAACTCCATGA & $58^{\circ} \mathrm{C}, \mathrm{D}$ & 613 \\
\hline $\mathrm{vi}$ & ACGATCACCCGACTTCATGT & TTTAACСТСТСТGATAАСТСТTTGC & $58^{\circ} \mathrm{C}, \mathrm{D}$ & 646 \\
\hline vii & TGGGAAGCAATTTCCAACAT & AGTGCAATGGCACGATCTC & $58^{\circ} \mathrm{C}, \mathrm{D}$ & 589 \\
\hline viii & CAGCTAATTGGGAGGCTGAG & AAACCAAAACAACС СТGAA & $58^{\circ} \mathrm{C}, 3$ & 543 \\
\hline ix & ACTTGGCATCTCCССАTTC & TTGTGTCTGCCACATGGTGT & $58^{\circ} \mathrm{C}, \mathrm{D}, 3$ & 555 \\
\hline$x$ & TCAAAGTAATAATGGCAACACAA & TGAAAGTСТСАТССАТGАСТАAGC & $58^{\circ} \mathrm{C}, \mathrm{D}$ & 561 \\
\hline xi & GAATCCAGACATGTTGGTCAGA & TGCAAGAATGAAGAGCAGACA & $60^{\circ} \mathrm{C}$ & 482 \\
\hline xii & ПТСАСТGАСАТАСТGСССАСА & AGGCAGGAGAATTGCTTGAA & $53^{\circ} \mathrm{C}, \mathrm{D}$ & 580 \\
\hline xiii & CCTGTCACCTAGGCTGGAAT & CCCGGATTACTTAGGGATAGG & $60^{\circ} \mathrm{C}$ & 517 \\
\hline xiv & САСТТССТСТТGССССАGТА & AGGCAAGTCTCСТGTCTCCA & $60^{\circ} \mathrm{C}$ & 553 \\
\hline$x V$ & CTTCATGTTAGAAAATGCAAAGAA & AGATCCATTTCCACCAGAGC & $58^{\circ} \mathrm{C}, \mathrm{D}$ & 556 \\
\hline xvi & GCTTGCCAGCATATITGAGC & ССTTTGATTCTTTGTAAAATTITGATT & $58^{\circ} \mathrm{C}, \mathrm{D}, 4$ & 508 \\
\hline \multicolumn{5}{|c|}{$3^{\prime}$ UTR } \\
\hline & ТСССТТАТТGТСССТТССАА & САССТGAGGTCAGGAGTTCG & $57^{\circ} \mathrm{C}$ & 506 \\
\hline ii & CACСACGССТАGСТСАTTTT & TCССТGATTTСTGTAGGGTGTT & $58^{\circ} \mathrm{C}$ & 523 \\
\hline iii & ACAAGGCACAGCAAGGGTAA & TGGGGGCATGTAACTAGCTC & $62^{\circ} \mathrm{C}$ & 538 \\
\hline iv & СССТСТGTGСTGAAGTGTCA & TGGGAAAAGTGCATGTGAAA & $58^{\circ} \mathrm{C}$ & 541 \\
\hline $\mathrm{v}$ & TGGCTATGTTGAGAGAGGAAAA & CCATGCCCAGCTAATTITTG & $60^{\circ} \mathrm{C}$, nested & 505 \\
\hline $\mathrm{vi}$ & TCAAGACCAGCCTAGCCAAC & CCAGCCTAGATGTTGCTGTG & $65^{\circ} \mathrm{C}$ & 517 \\
\hline vii & GGGCTCACCCACATTATGAA & AGCCCTGAAAAGCAGAGAAA & $58^{\circ} \mathrm{C}$ & 543 \\
\hline viii & GGCTTTAGGTGAGCAGTTCC & TCTCATGGTATTCGCCGTTT & $58^{\circ} \mathrm{C}$ & 507 \\
\hline ix & TGGACACGCAGTCCACAT & GGTGGACCCTAATCCAGCAT & $60^{\circ} \mathrm{C}$ & 502 \\
\hline $\mathrm{x}$ & CATGATGCTCTCССTGTGTC & CCACAATAGTGAGTGGCTGGT & $62^{\circ} \mathrm{C}$ & 519 \\
\hline $\mathrm{xi}$ & TCCCAAACTAAACCACCTTTGT & AGGGAATGTTGATTGGTTGG & $58^{\circ} \mathrm{C}$ & 370 \\
\hline xii & TGAGACAGGGTCTTGCTCTG & CCTGATGCATTTTCCTGCT & $57^{\circ} \mathrm{C}$ & 453 \\
\hline xiii & ATGGCTGGCCTTGCATTA & TCAACTTCCATCATGTTGTTCC & $58^{\circ} \mathrm{C}$ & 549 \\
\hline \multicolumn{5}{|c|}{ (B) Microsatellite analysis } \\
\hline$i$ & TAGATTGAAGTGGACTTTATCTGGG & TTAGCCAAACTAAGTCATTTGGAAG & $58^{\circ} \mathrm{C}$ & 115 \\
\hline ii & ATAAGGACAAAAACCTGCСTTAGTT & GCCGACTTATTAATACAAGTCCAGA & $58^{\circ} \mathrm{C}$ & 179 \\
\hline \multicolumn{5}{|c|}{ (C) SNP analysis } \\
\hline $\mathrm{i}$ & СGGTTATGAAAGAАСТTССАААТАсаT & TGCСTCAGGAGAGAATCCTT & $54^{\circ} \mathrm{C}$ & 148 \\
\hline ii & TCССТTATTGTСССТTССАA & GCCCTTGGAATGTGTCTTTT & $58^{\circ} \mathrm{C}$ & 229 \\
\hline iii & TСССТTATTGTСССТТССАА & ACAGTAAAGAAGTGGGCCCaT & $54^{\circ} \mathrm{C}$ & 244 \\
\hline iv & ACACСТGGСТАATTTAAAAATGTTgTA & TGTGCTGGСTCACACTTGTA & $60^{\circ} \mathrm{C}$ & 137 \\
\hline
\end{tabular}

D: DMSO; Boldface numbers: respective TTR exons amplified by the set of primers. 
latter group since they were already over 60 years of age at the time the study was initiated. The analysis also included 54 Swedish subjects (20 carriers and 34 controls) and 53 Portuguese controls.

Genotyping was performed by PCR amplification of the target sequences using primers with mismatched nucleotides to create artificial restriction sites for allele detection. The SNPs, designated 5'III (A/G, nt 2970, 5' UTR), 3'I (C/T, nt $21,3^{\prime}$ UTR), $3^{\prime} \mathrm{II}$ (C/T, nt 162, $3^{\prime}$ UTR) and $3^{\prime} \mathrm{V}$ (T/C, nt $4934,3^{\prime}$ UTR), were amplified using the primers shown in Table 2C, in which the lowercase letters are the mismatched nucleotides. The samples were denatured at $96^{\circ} \mathrm{C}$ for $6 \mathrm{~min}$ and cycled 35 times with denaturation at $94^{\circ} \mathrm{C}$ for $30 \mathrm{~s}$, annealing at temperatures specified above for $30 \mathrm{~s}$ and extension at $72^{\circ} \mathrm{C}$ for $30 \mathrm{~s}$, followed by a final extension at $72^{\circ} \mathrm{C}$ for $10 \mathrm{~min}$. The amplicons were digested for $\sim 14 \mathrm{~h}$ with $10 \mathrm{U}$ of $\mathrm{NdeI}\left(5^{\prime} \mathrm{III}\right.$, for which the A-to-G transition destroys the restriction site), BsmI ( $3^{\prime} \mathrm{I}$, for which the C-to-T transition creates a natural restriction site), NcoI ( $3^{\prime} \mathrm{II}$, for which the C-to-T transition destroys the restriction site) and BsrGI $\left(3^{\prime} \mathrm{V}\right.$, for which the T-to-C transition creates a restriction site). Digested products were electrophoresed in 4-20\% TBE polyacrylamide gels (Invitrogen, Carlsbad, CA, USA), stained with ethidium bromide and visualized under ultraviolet (UV) light. Genotyping of TTR intronic SNPs was performed as described elsewhere. ${ }^{12}$

\section{Haplotype determination}

The linkage phase of haplotypes was inferred by pedigree analysis in familial cases. For singleton subjects, haplotypes were assigned unambiguously in case of complete homo- zygozity or heterozygozity at a single site. Complex cases with more than one heterozygous site were resolved by identification of a set of putative haplotypes by 'subtracting' the unambiguous haplotypes. ${ }^{17}$

\section{Statistical analysis}

Statistical analyses were performed using the GraphPad Instat 3.01 package (GraphPad Software, San Diego, CA, USA) and StatXact, Version 5 (Cytel Software, Cambridge, MA, USA). The null hypothesis of no linkage disequilibrium was calculated for biallelic and multiallelic loci using a Fisher exact test (FET) through an exact calculation of the hypergeometric distribution, as implemented by StatXact. $^{18}$

Portuguese and Swedish populations were evaluated independently. Carrier and control chromosomes were compared with respect to microsatellite alleles (13) and their respective haplotypes (14) (Tables 3 and 4) 5' CA repeat alleles (2) (Table 6), flanking SNPs (8) and their haplotypes (6) (Tables 8 and 9). When both haplotypes and SNPs were available, only the haplotype comparisons were used, since they subsumed the individual SNPs. To account for the performance of 22 comparisons (14 microsatellite haplotypes, 2 CA repeat alleles, 6 SNP-determined haplotypes), we utilized a very conservative estimate of significance, that is, $P<0.0023$ (Bonferroni). Significant values are indicated in bold type.

Classical and late-onset FAP patients were compared with respect to the haplotype distribution on the mutation carrier and noncarrier chromosomes. For the V30M carrier subsets, the FET was conducted using the 'combined allele'

Table 3 Allelic associations for FAP families

\begin{tabular}{|c|c|c|c|c|c|c|c|c|c|}
\hline Marker and alleles & \multicolumn{9}{|c|}{ No. (\%) of chromosomes } \\
\hline $\begin{array}{l}\text { D185457: } \\
1-114 b p \\
2-116 b p \\
3-118 b p^{a} \\
4-120 b p \\
5-122 b p \\
6-124 b p \\
7-126 b p\end{array}$ & $\begin{array}{c}0(0) \\
0(0) \\
26(100) \\
0(0) \\
0(0) \\
0(0) \\
0(0)\end{array}$ & $\begin{array}{l}0(0) \\
0(0) \\
12(100) \\
0(0) \\
0(0) \\
0(0) \\
0(0)\end{array}$ & $\begin{array}{c}0(0) \\
0(0) \\
38(100) \\
0(0) \\
0(0) \\
0(0) \\
0(0)\end{array}$ & $\begin{array}{c}1(1.3) \\
1(1.3) \\
63(78.8) \\
8(10.0) \\
3(3.8) \\
1(1.3) \\
3(3.8)\end{array}$ & $\begin{array}{c}1(6.3) \\
0(0) \\
13(81.3) \\
0(0) \\
0(0) \\
1(6.3) \\
1(6.3)\end{array}$ & $\begin{array}{c}2(2.1) \\
1(1.0) \\
76(79.2) \\
8(8.3) \\
3(3.1) \\
2(2.1) \\
4(4.2)\end{array}$ & 0.4025 & 1.000 & 0.2029 \\
\hline $\begin{array}{l}\text { D18S456: } \\
1-233 b p \\
2-235 b p^{+} \\
3-237 b p \\
4-239 b p \\
5-241 b p \\
6-243 b p\end{array}$ & $\begin{array}{c}5(19.2) \\
21(80.8) \\
0(0) \\
0(0) \\
0(0) \\
0(0)\end{array}$ & $\begin{array}{c}0(0) \\
12(100) \\
0(0) \\
0(0) \\
0(0) \\
0(0)\end{array}$ & $\begin{array}{c}5(13.2) \\
33(86.8) \\
0(0) \\
0(0) \\
0(0) \\
0(0)\end{array}$ & $\begin{array}{l}23(28.8) \\
36(45.0) \\
21(26.2) \\
0(0) \\
0(0) \\
0(0)\end{array}$ & $\begin{array}{l}5(31.2) \\
8(50.0) \\
3(18.8) \\
0(0) \\
0(0) \\
0(0)\end{array}$ & $\begin{array}{l}28(29.2) \\
44(45.8) \\
24(25.0) \\
0(0) \\
0(0) \\
0(0)\end{array}$ & 0.0007 & 0.0147 & $<0.0001$ \\
\hline
\end{tabular}

Tests of the null hypothesis of no linkage disequilibrium calculated as described in Material and methods. FET: Fisher exact test. ${ }^{\text {aV30M-associated }}$ allele. 
Table 4 Distribution of microsatellite haplotypes among Portuguese and Swedish kindreds

\begin{tabular}{|c|c|c|c|c|c|c|}
\hline \multirow{3}{*}{$\begin{array}{l}\text { Haplotypes } \\
\text { D18S457-D185456 }\end{array}$} & \multicolumn{6}{|c|}{ No. of chromosomes and haplotype frequencies } \\
\hline & \multicolumn{2}{|c|}{ Portuguese } & \multirow{2}{*}{ FET P-value } & \multicolumn{2}{|c|}{ Swedish } & \multirow{2}{*}{ FET P-value } \\
\hline & Carrier $(n=26)$ & Noncarrier $(n=80)$ & & Carrier $(n=12)$ & Noncarrier $(n=16)$ & \\
\hline $\begin{array}{l}3-2 \\
3-1 \\
3-3\end{array}$ & $\begin{array}{r}21(0.81) \\
5(0.19) \\
\end{array}$ & $\begin{array}{l}31(0.39) \\
17(0.21) \\
15(0.19)\end{array}$ & & $\begin{array}{c}12(100.0) \\
-\end{array}$ & $\begin{array}{l}6(0.38) \\
4(0.25) \\
3(0.19)\end{array}$ & \\
\hline $\begin{array}{l}\text { Others } \\
10 \text { hap } \\
3 \text { hap }\end{array}$ & - & $17(0.21)$ & 0.0840 & - & $3(0.19)$ & 0.0072 \\
\hline
\end{tabular}

Tests of the null hypothesis of no linkage disequilibrium calculated as described in Material and methods. FET: Fisher exact test. ${ }^{*}$ Low-frequency haplotypes are not shown.

Table 5 Microsatellite haplotypes in carrier and noncarrier chromosomes of Portuguese FAP patients by group of disease onset

\begin{tabular}{|c|c|c|c|c|c|c|c|c|c|}
\hline \multirow{3}{*}{ Disease onset } & \multicolumn{9}{|c|}{ Microsatellite haplotypes } \\
\hline & \multicolumn{2}{|c|}{ Carrier chrom. } & \multirow{2}{*}{ FET P-value } & \multicolumn{4}{|c|}{ Noncarrier chrom. } & \multirow{2}{*}{ Comb allele FET $P$} & \multirow{2}{*}{ Multi allele FET $P$} \\
\hline & $3-1$ & $3-2$ & & $3-1$ & $3-2$ & $3-3$ & Other & & \\
\hline Classical & 6 & 13 & \multirow{2}{*}{0.3245} & 5 & 2 & 5 & 7 & \multirow{2}{*}{0.0128} & \multirow{2}{*}{0.0419} \\
\hline Late & 9 & 9 & & 4 & 9 & 1 & 4 & & \\
\hline
\end{tabular}

The haplotypes are defined by D18S457 and D18S456.FET: Fisher exact test. Comb allele: the Fisher exact test was performed on the number of chromosomes bearing the 3-2 haplotype, and the combined number of chromosomes with haplotypes 3-1, 3-3 and others. Multi allele: the Fisher exact test was conducted without combining any haplotypes.

and the 'multiallele' methods. In the 'combined allele' method, the haplotype that is over-represented among V30M chromosomes was compared to all other haplotypes combined, whereas the in 'multiallele' method the haplotypes were not combined.

\section{Results}

Microsatellite allelic and haplotypic associations

The allelic distributions of the polymorphic microsatellite markers D18S457 and D18S456 are shown in Table 3. The 118-bp allele (3) of D18S457 was associated with V30M in $100 \%$ of the cases. However, due to the high frequency of allele 3, which is in accord with the estimated frequency in Caucasians (0.75) (GDB:2396675), it did not differ significantly among carrier and noncarrier chromosomes. The 235-bp allele (2) of D18S456 was significantly associated with the mutation on $86.8 \%$ of carrier chromosomes versus $45.8 \%$ of noncarrier chromosomes. When the hypothesis of linkage disequilibrium was tested for the Portuguese and Swedish populations independently, the associations remained significant for D18S456, but nonsignificant for D18S457 due to the high frequency of allele 3 in both populations and the relatively small sample size for the Swedes.
In all, 14 of a possible 42 haplotypes for D18S457D18S456 were observed in our study population. Table 4 summarizes the microsatellite haplotype distribution in carrier and noncarrier chromosomes, respectively. Haplotypes 3-2 and 3-1 were associated with V30M in the Portuguese, whereas, among the Swedes, 3-2 was the only haplotype found in carrier chromosomes. Among the remaining 12 haplotypes identified, 11 were observed in the Portuguese and four in the Swedes. The infrequent haplotypes were only found in one or two chromosomes (not shown).

The most frequent haplotype associated with V30M in Portuguese families was equally distributed among individuals with classical and late onset (Table 5). In contrast, the analysis of noncarrier chromosomes in $37 \mathrm{~V} 30 \mathrm{M}$ patients revealed a possible significant association between haplotype $3-2$ and late onset ( $P=0.0128$ by FET; odds ratio: 8.50 ; 95\% CI: $1.503-48.07$, when compared to the frequencies of all other haplotypes combined), suggesting a possible modulatory effect on the age of onset by a factor encoded in the interval on the noncarrier chromosome. The data were also analyzed without combining haplotypes, using an exact calculation of the hypergeometric distribution $(\text { FET })^{18}$ as implemented by StatXact. Although an exact $P$ value of 0.0419 was obtained, the differences were not 
Table 6 Allele frequencies of a polymorphic CA-repeat in transthyretin $5^{\prime}$ untranslated region in the Portuguese and Swedish populations

\begin{tabular}{|c|c|c|c|c|c|c|c|c|c|}
\hline \multirow[b]{3}{*}{ SNP } & \multirow[b]{3}{*}{ Alleles } & \multirow[b]{3}{*}{ Location } & \multirow[b]{3}{*}{ Position } & \multicolumn{6}{|c|}{ No. of chromosomes and allele frequencies } \\
\hline & & & & \multicolumn{2}{|c|}{ Portuguese } & \multirow{2}{*}{ FET P-value } & \multicolumn{2}{|c|}{ Swedish } & \multirow{2}{*}{ FET P-value } \\
\hline & & & & Carrier $(n=30)$ & Noncarrier $(n=62)$ & & Carrier $(n=9)$ & Noncarrier $(n=9)$ & \\
\hline \multirow[t]{2}{*}{ V } & $(C A)_{9}$ & $5^{\prime}$ UTR & 5917 & - & $19(0.31)$ & \multirow{2}{*}{0.0002} & - & $3(0.33)$ & \multirow{2}{*}{0.206} \\
\hline & $(C A)_{10}$ & & & $30(1.0)$ & $43(0.69)$ & & $9(1.0)$ & $6(0.67)$ & \\
\hline
\end{tabular}

FET: Fisher exact test.

significant after correction for multiple comparisons. A similar analysis without haplotype 3-2 resulted in a lack of statistical significance $(P=0.4778)$, suggesting that the possible association is wholly due to this most common haplotype.

The $5^{\prime}$ untranslated region CA dinucleotide repeat (nt -643 , relative to TTR cds) was found to be polymorphic with two alleles identified in 92 Portuguese and 18 Swedish chromosomes (Table 6). The (CA) 10 allele was associated with V30M in both populations, but it did not approach statistical significance for the Swedes, presumably because of the smaller size of this subset. However, the association with the mutation was not exclusive as $31.0 \%$ of the noncarrier chromosomes bore the allele. The $(\mathrm{CA})_{9}$ allele was not found on any of the 39 carrier chromosomes and accounted for an average of $32 \%$ of the noncarrier chromosomes in the two populations.

\section{TTR sequence variation survey}

Human TTR, located on chromosome 18q11.2-q12.1, ${ }^{19}$ has four exons distributed across approximately $7.6 \mathrm{~kb}$ of genomic DNA. A region of $19888 \mathrm{bp}$ was sequenced in 10 Portuguese V30M subjects (see Material and methods). A contiguous baseline reference sequence for the target region was obtained from GenBank. DNA variants were identified by matching each individual's DNA sequence to the reference sequence and to that of the other subjects. To minimize ambiguities, the sequence was obtained from both strands. In all, 16 variable sites were identified among 11 individuals (Figure 1), of which the six intronic sites had previously been described. ${ }^{10}$ Of the 10 newly identified polymorphisms, eight result from single-base substitutions (seven transitions, one transversion), and two from insertion/deletions reflecting copy number changes in dinucleotide sequences. The variable site designated $5^{\prime} \mathrm{I}$ was observed in a single chromosome among the 20 chromosomes. Variable sites $5^{\prime} \mathrm{II}, 3^{\prime} \mathrm{IV}$ and $3^{\prime} \mathrm{VI}$ were identified in three of the 10 subjects ( $3 / 20$ chromosomes), suggesting that the allelic variants are common. Polymorphism $3^{\prime}$ IV represents the only transversion (T-G) among the eight single-base substitutions identified here, while variable site $3^{\prime} \mathrm{VI}$ constitutes an insertion/deletion with two alleles resulting in a qualitative rather than quantitative change, as the insertion of a CT dinucleotide in a CT-repeat tract accompanies the deletion of a CA from an adjacent CArepeat sequence.

Three sites were identified only on single chromosomes. Site $5^{\prime} \mathrm{I}$, previously referred to, probably represents a rare polymorphism. Site $3^{\prime} \mathrm{I}$ is a confirmed rare polymorphism (shown below), while site $3^{\prime} \mathrm{III}$, not present in any of the 20 chromosomes initially surveyed, was identified in a single kindred as a consequence of extended studies (see below).

To investigate a possible association with disease onset, the polymorphisms were organized in haplotypes. Six haplotypes resulted from these variations (Table 7). Three subjects were homozygous for the most common haplotype and all had developed the first clinical symptoms at an early age (22, 23 and 24 years of age). The two other early-onset individuals (onset at 21 and 22 years of age) were heterozygotes with haplotypes $\mathrm{i}-\mathrm{vi}$, and $\mathrm{i}-\mathrm{ii}$, respectively. Interestingly, the individuals bearing the singlesubstitution haplotypes (ii, iii and iv) were late onset with disease symptoms developing at ages 63 and 64 years and an asymptomatic carrier aged 74 years. The remaining lateonset individuals (onset at 72 years of age and an asymptomatic carrier aged 72 years) were heterozygotes bearing haplotypes i and ii. Although these results could be indicative of an association between particular haplotypes (or alleles) and the age of disease onset, they could not be statistically validated since the sample was too small and the distributions were complex. No mutations other than V30M were identified in the screened subjects, except for G6S, a nonsynonymous substitution described as a neutral polymorphism, ${ }^{20}$ identified in a compound heterozygote. The individual heterozygous for G6S and a subject homozygous for V30M both displayed classical onset and were homozygous for haplotype $i$, the most frequent haplotype.

\section{SNP haplotype analysis}

We extended the analysis of four SNPs to 97 singletons (i.e. single representatives of distinct FAP families, V30M carriers), 20 Swedish carriers (including familial cases), 53 Portuguese and 34 Swedish controls. A total of 234 


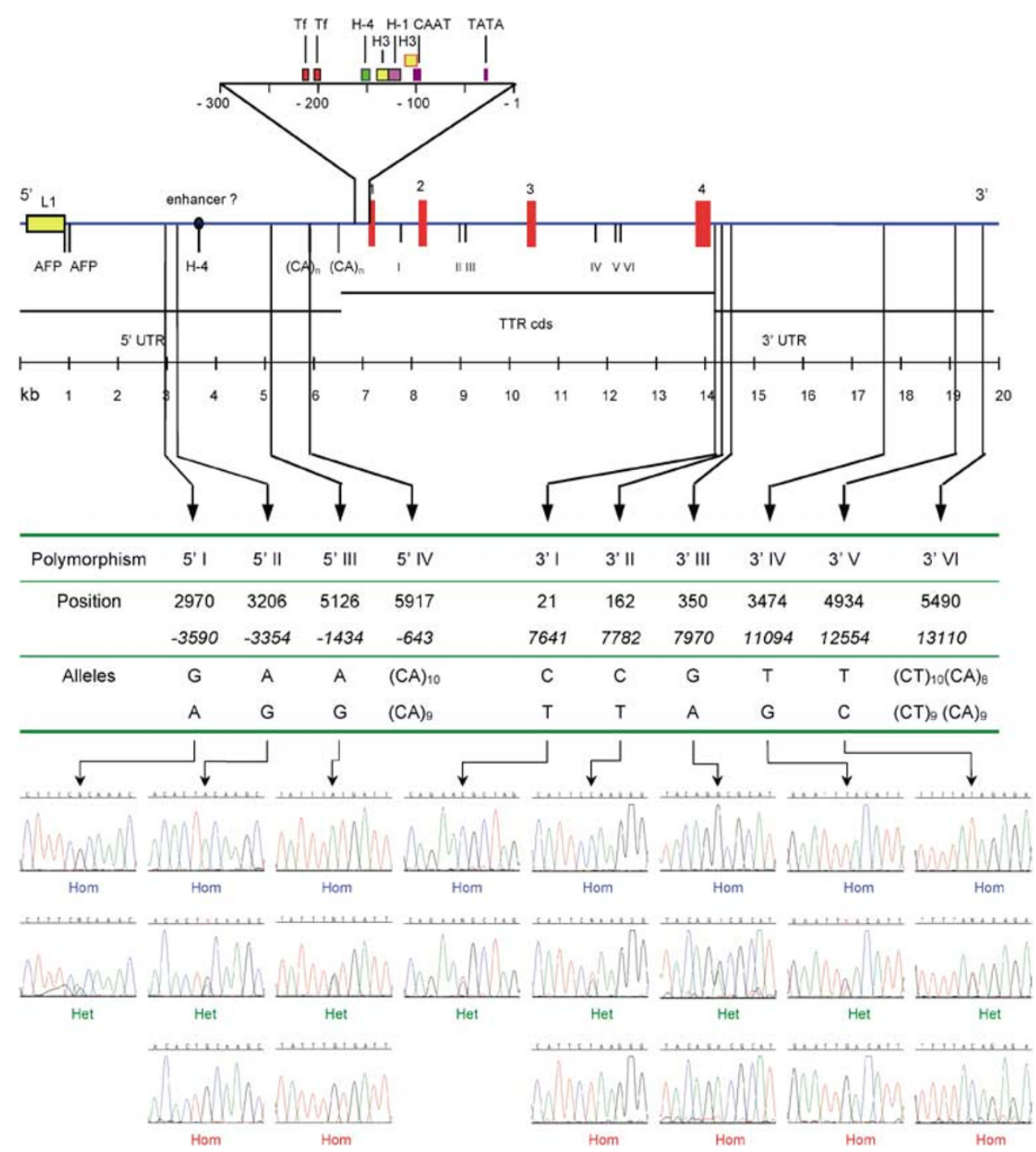

Figure 1 Schematic representation of the genomic interval surveyed by direct sequencing and polymorphisms newly identified with respective DNA sequence electropherograms. The numbering in Italic refers to the position of the polymorphisms relative to TTR cds (GenBank M11518); TTR exons are numbered from 1 to 4 ; the intronic SNPs identified by Yoshioka et $a l^{10}$ are numbered from I to $\mathrm{Vl}$; (CA $)_{n}$ : CA-dinucleotide repeats. From Sakaki et al $l^{16}$ - TATA: TATA box; CAAT box; $\mathrm{H}-1, \mathrm{H} 3, \mathrm{H}-4$ : binding sites for hepatocyte nuclear factors HNF-1, HNF-3 and HNF-4, respectively; Tf: common motif to Tf-LF1, Tf-LF-2 and LF-A1; enhancer: a region highly homologous to a tissue-specific enhancer of the mouse TTR gene; AFP: binding site for AFP-1 factor. Hom in blue font: homozygous for the upper allele; Het: heterozygous; Hom in red font; homozygous for the bottom allele.

chromosomes from V30M carriers and 174 control chromosomes were genotyped by restriction analysis for polymorphisms $5^{\prime} \mathrm{III}, 3^{\prime} \mathrm{I}, 3^{\prime} \mathrm{II}$ and $3^{\prime} \mathrm{V}$. Data on the allelic frequencies are shown in Table 8. Alleles $\mathrm{A}, \mathrm{C}$ and $\mathrm{T}$ (sites $5^{\prime} \mathrm{III}, 3^{\prime} \mathrm{II}$ and $3^{\prime} \mathrm{V}$, respectively) were strongly associated with V30M in the Portuguese. Among Swedes, the allele frequencies did not differ much between carriers and controls, suggesting that the alleles associated with the mutation are also very common in the general population. Overall, the alleles specified above were present in all
V30M individuals, either as homo- or heterozygotes, except for a single subject who was homozygous for the alternative nucleotides (discussed below). Site $3^{\prime} \mathrm{I}$ was a rare polymorphism among the Portuguese (not determined for the Swedes), with the most common allele accounting for approximately $99 \%$ of the total number of chromosomes.

Haplotypes for $5^{\prime} \mathrm{III}-3^{\prime} \mathrm{II}-3^{\prime} \mathrm{V}$ were constructed as described in Material and methods. Of the eight possible combinations, six haplotypes were identified (Table 9). Fisher's exact analysis was used to test the null hypothesis 
Table 7 Frequencies of TTR haplotypes defined by the newly discovered SNPs among 20 FAP individuals surveyed by genomic sequencing

\begin{tabular}{|c|c|c|c|c|c|c|c|c|c|c|c|c|}
\hline \multirow[b]{2}{*}{ Haplotype } & \multicolumn{11}{|c|}{ Sequence } & \multirow[b]{2}{*}{ Frequency } \\
\hline & $5^{\prime} 1$ & $5^{\prime} 11$ & $5^{\prime} I I I$ & $5^{\prime} \mathrm{IV}$ & $I H$ & $3^{\prime} 1$ & $3^{\prime} \|$ & $3^{\prime \prime}$ III & $3^{\prime} I V$ & $3^{\prime} \mathrm{V}$ & $3^{\prime} \mathrm{VI}$ & \\
\hline i & G & A & A & $(C A)_{10}$ & 1 & C & C & G & T & T & $(\mathrm{CT})_{10}(\mathrm{CA})_{8}$ & $0.65(13 / 20)$ \\
\hline ii & G & G & G & $(\mathrm{CA})_{9}$ & III & C & $\mathrm{T}$ & G & G & C & $(\mathrm{CT})_{9}(\mathrm{CA})_{9}$ & $0.15(3 / 20)$ \\
\hline iii & A & A & A & $(C A)_{10}$ & 1 & C & C & G & T & $\mathrm{T}$ & $(\mathrm{CT})_{10}(\mathrm{CA})_{8}$ & $0.05(1 / 20)$ \\
\hline iv & G & A & A & $(C A)_{9}$ & I & C & C & G & $\mathrm{T}$ & $\mathrm{T}$ & $(\mathrm{CT})_{10}(\mathrm{CA})_{8}$ & $0.05(1 / 20)$ \\
\hline $\mathrm{v}$ & G & A & A & $(C A)_{10}$ & 1 & T & C & G & $\mathrm{T}$ & $\mathrm{T}$ & $(\mathrm{CT})_{10}(\mathrm{CA})_{8}$ & $0.05(1 / 20)$ \\
\hline vi & G & A & A & $(\mathrm{CA})_{10}$ & i & C & $\mathrm{T}$ & G & $\mathrm{T}$ & $\mathrm{T}$ & $(\mathrm{CT})_{10}(\mathrm{CA})_{8}$ & $0.05(1 / 20)$ \\
\hline
\end{tabular}

IH - intragenic haplotypes (nomenclature adopted by Yoshioka et $a l^{9}$ ).

Table 8 Allele frequencies of four newly identified SNPs in transthyretin flanking regions in the Portuguese and Swedish populations

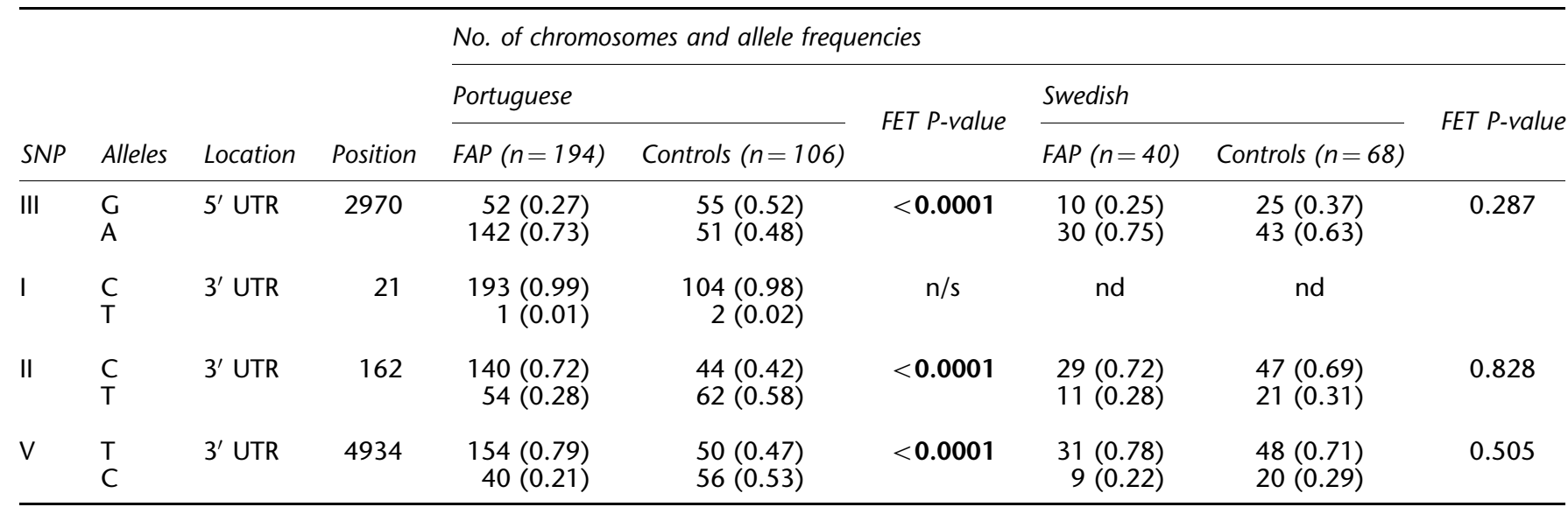

FET: Fisher exact test; n/s: nonsignificant; nd: not determined.

Table 9 Frequencies of haplotypes defined by three TTR flanking SNPs among V30M carriers and controls in the Portuguese and Swedish populations

\begin{tabular}{|c|c|c|c|c|c|c|}
\hline \multirow{2}{*}{ Haplotype } & \multicolumn{6}{|c|}{ No. of chromosomes and haplotype frequencies } \\
\hline & \multicolumn{2}{|l|}{ Portuguese } & FET P-value & \multicolumn{2}{|l|}{ Swedish } & FET P-value \\
\hline$A-C-T$ & $130(0.67)$ & $44(0.41)$ & & $28(0.70)$ & $42(0.62)$ & \\
\hline G-T-C & $37(0.19)$ & $51(0.48)$ & & $9(0.22)$ & $20(0.29)$ & \\
\hline A-T-T & $10(0.05)$ & $2(0.02)$ & & $2(0.05)$ & $1(0.02)$ & \\
\hline A-T-C & $3(0.02)$ & $5(0.05)$ & & - & - & \\
\hline
\end{tabular}

FET: Fisher exact test.

of no linkage disequilibrium. It confirmed the strong association between haplotype A-C-T and V30M, as suggested by the sequencing results, the allelic distributions and the frequency of homozygote carriers (42/117). Although no such association was found for the Swedish population, A-C-T was the haplotype bearing the V30M mutation. Homozygote carriers and the use of familial cases established the linkage phase and validated the association of the haplotype - also common in the general population - to the mutation. Of the four least frequent haplotypes, only two were identified in the Swedes, occurring at a frequency similar to that seen in the Portuguese.

To investigate a possible effect of the noncarrier haplotype in disease onset, the Portuguese subjects were divided into the following groups: classical onset (below 
age 40 years, $n=58$ ) and late onset (above age 50 years, $n=39$ ). The distribution of haplotypes between the two groups was not significantly different $(P=0.251$; $\chi^{2}=6.612,5$ d.f.), suggesting that the potential modulatory effect described above would not be located this close to TTR.

\section{A new V30M-associated haplotype in the Portuguese population}

The analysis of the nucleotide substitutions reported above resulted in the identification of a different set of alleles in association with the V30M mutation. Among the 117 V30M carriers surveyed, we identified one subject homozygous for alleles $\mathrm{G}, \mathrm{T}$ and $\mathrm{C}$ (sites $5^{\prime} \mathrm{III}, 3^{\prime} \mathrm{II}$ and $3^{\prime} \mathrm{V}$, respectively), bearing an unambiguous haplotype that would require several recombination events to arise from intragenic haplotype I. Using direct genomic sequencing, the individual (an asymptomatic carrier aged 53 years, designated $\mathrm{N}$ ) was shown to carry the extended haplotype ii: G-G-G-(CA) ${ }_{9}-\mathrm{C}-\mathrm{T}-\mathrm{G}-\mathrm{G}-\mathrm{C}-(\mathrm{CT})_{9}(\mathrm{CA})_{9}$, which includes intragenic haplotype III, a haplotype found for the first time in association with V30M in a Portuguese. It must be noted however, that the proband's father, even though of Portuguese nationality, had been abandoned in childhood. Hence, the individual may not be of long-standing Portuguese descent.

In the same kindred, a new SNP (not observed among the 10 subjects surveyed) was identified, consisting of a G-A transition and designated $3^{\prime}$ III. Two noncarrier sibs were also genotyped for polymorphisms $5^{\prime} \mathrm{III}, 3^{\prime} \mathrm{II}$ and $5^{\prime} \mathrm{V}$. The pedigree and respective haplotypes are shown in Figure 2. Subject $\mathrm{N}$ and his affected sib were homozygous for extended haplotype ii (intragenic haplotype III), whereas the remaining relatives were heterozygous for $\mathrm{i}$ and ii (intragenic haplotypes I and III), with the mutation associated with the latter. Thus, the mutation had been inherited from the father, but it could not be determined whether it had arisen in this individual or in his ancestors.

Interestingly, subject $\mathrm{N}$ and his affected sib were homozygous for allele A of SNP 3'III, implying that the nonaffected mother was also a carrier of this apparently rare polymorphism. The screening of TTR exons did not show additional mutations in the carrier siblings, but revealed the presence of a G6S variant in the father lying on the allele opposite to the mutation and associated with haplotype I.

\section{Discussion}

Our analysis of TTR and neighboring regions by means of microsatellite- and SNP-based haplotype analysis coupled with genomic sequencing in Portuguese and Swedish FAP kindreds has provided more extensive knowledge of the TTR gene and its surroundings. We have characterized the

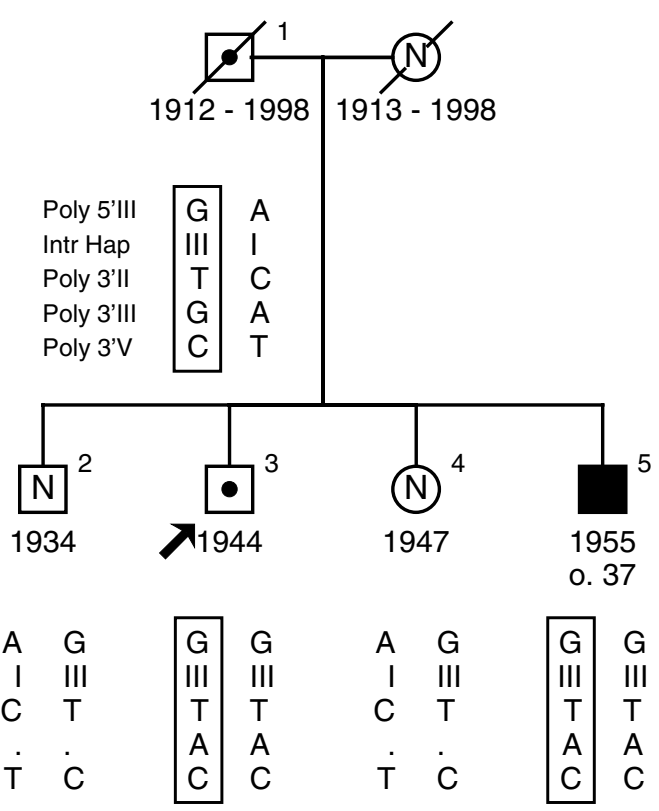

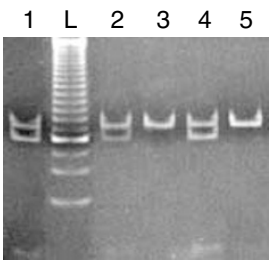

5’ III

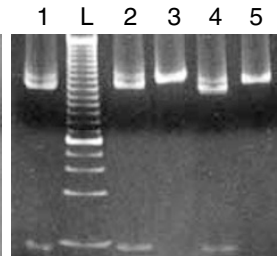

3' II

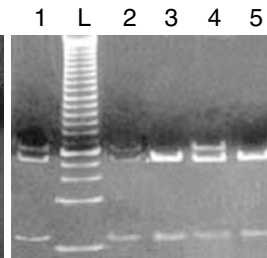

3' V
Figure 2 Pedigree of the kindred bearing a new diseaseassociated haplotype and respective RFLP assays for polymorphisms $5^{\prime} \mathrm{III}, 3^{\prime} \mathrm{Il}$ and $3^{\prime} \mathrm{V}$. The lanes numbered from 1 to 5 refer to the RFLP analyses of the corresponding individuals for each of the specified polymorphisms. Genotypes for polymorphisms 5'III, 3'II, 3'III (exclusively identified in this family), $3^{\prime} \mathrm{V}$ and the classical intragenic haplotypes are shown below each subject, $5^{\prime}$ to $3^{\prime}$. Affected individuals are represented by black symbols; asymptomatic V30M carriers are identified by dot-containing symbols; noncarriers are indicated by $\mathrm{N}$-containing symbols. Boxed haplotypes carry the V30M mutation. Dates indicate the year of birth and, when applicable, year of death. Arrow: proband, individual N; o: age of onset; Intr Hap: intragenic haplotype; L: 25-bp DNA ladder.

TTR UTRs and described a V30M-bearing haplotype not previously seen in the Portuguese population.

The observation that haplotype 3-2 was common in lateonset $(n=9 / 18)$ but not in early-onset cases $(n=2 / 19)$, relative to all other haplotypes together $(p=0.0127)$ (Table 5), suggested that there may be a modulating effect on the age of onset in FAP V30M patients exerted by a locus within or closely linked to the interval defined by $D 18 S 457$ and D18S456, and associated with haplotype 3-2 in the accompanying chromosome. Since the large number of possible haplotypes required multiple comparisons, when 
each haplotype was evaluated separately, the observation did not achieve statistical significance in that analysis; nonetheless it was suggestive of an influence of the noncarrier chromosome. If it can be independently validated, the effect suggested here conforms to a model in which a specific allele at a locus close to the wild-type TTR on that chromosome modulates the initiation of the first symptoms of disease through a trans-acting mechanism. The interval defined by microsatellite markers D18S457 and D18S456 on 18q contains two genes with protein products of unknown function and six potential genes based on observed ESTs. Beta-1,4-galactosyltransferase $6(B 4 G A L-T 6)$ and meprin A beta $(M E P 1 B)$, as well as four genes with protein products of unknown function and seven possible genes related to known ESTs, map to the $700 \mathrm{~kb}$ region separating the marker interval from TTR (Public Genome Database).

Within the interval of $\sim 20 \mathrm{~kb}$ containing the TTR coding sequence, all the known regulatory regions and additional contiguous $3^{\prime}$ and $5^{\prime}$ sequences, we identified 10 new polymorphisms. Among the six haplotypes that could be constructed, the two most frequent intragenic haplotypes were found: haplotype I, on 17 chromosomes, and haplotype III, on the remaining three and not in association with V30M. No relationship could be established between the variable sites (and resulting haplotypes) and a particular mode of disease onset given the small sample; nonetheless, three of the five late-onset subjects were carriers of distinct haplotypes with a single heterozygous site, an occurrence not observed among the early-onset cases. Overall, the amount of variation found in the 20 chromosomes surveyed in this study (including coding sequence mutations) constitutes the expected level of variation, with a nucleotide diversity of $\sim 0.001$ (or about one variable site per $1000 \mathrm{bp}$ ), which falls within the range of reported values estimated from a conservative analysis of allelic variation obtained from a scan of the human sequence database $(0.001-0.003) .{ }^{21,22}$

Variable sites $5^{\prime} \mathrm{III}, 3^{\prime} \mathrm{II}$ and $3^{\prime} \mathrm{V}$ were typed in singleton and familial subjects from Portuguese and Swedish kindreds. All carriers were found to bear the haplotype associated with V30M, formed by alleles A, C and T, respectively. Linkage phase was established by familial cases and was in accordance to the phasing suggested by the genomic sequencing survey. The association of V30M with a single haplotype in this study is consistent with the reports of a sole intragenic disease-associated haplotype in these populations.

We identified one V30M asymptomatic carrier of possible Portuguese origin, who was homozygous for haplotype G-T-C, comprising intragenic haplotype III. Haplotype III has not previously been seen in association with V30M in Portuguese carriers, but had been found associated with the mutant allele in kindreds from Japan, France, Britain and Italy. ${ }^{10,23,24}$ In the Portuguese and
Japanese populations, intragenic haplotype III has been reported to account for 47.4 and $35.0 \%$ of the noncarrier chromosomes, respectively, thus representing the second most common haplotype in these countries. ${ }^{10,23}$ Hence, the occurrence of V30M in the context of this haplotype could have been the result of migration of a founder from another European population or a new V30M mutation in the setting of a haplotype common in Portugal. The latter would be consistent with the growing evidence for recurring mutation in TTR. In either case, our data constitute the first report of a haplotype other than haplotype I in association with FAP in Portugal.

Among the six TTR-flanking haplotypes identified in the Portuguese, haplotypes A-C-T (i) and G-T-C (ii) were observed to encompass intragenic haplotypes I and III, respectively. The correspondence, unequivocally established for several subjects who were also genotyped for the intronic SNPs, was corroborated by the haplotypic frequencies obtained here (Table 9). The remaining haplotypes (A-T-C; G-T-T, G-C-T and A-T-T) also included different intragenic haplotypes (as observed in some subjects). They may arise by recombination between flanking haplotypes $\mathrm{i}$ and ii, as did intragenic haplotype II from I and III and intragenic haplotype IV from I and V. The relationship between the TTR-flanking haplotypes described in this paper and the intragenic haplotypes described elsewhere is proposed in Table 10. The correspondence of the polymorphic CA stretch and the microsatellite markers, based on direct evidence (from individuals genotyped for the distinct types of polymorphisms) and inferential procedures, is also established.

Founder effects have clearly played a role in the population genetics of FAP. In spite of the growing evidence supporting recurring mutation in TTR to generate pathogenic variants in new chromosomal settings, the modest variation between Portuguese and Swedish carrier chromosomes within the surveyed intervals is not sufficient to exclude a single founder hypothesis in these two populations. Conversely, the high frequency of the diseaseassociated haplotype among noncarrier chromosomes, particularly in the Swedes (68\% for the SNP- and $37.5 \%$ for the microsatellite-defined haplotypes) may mask the occurrence of de novo mutations within the same haplotype. The study of microsatellite haplotypes defining a $2 \mathrm{cM}$ interval $(\sim 1.3 \mathrm{Mb})$ downstream of (and very close to) $T T R$ has broadened the survey for variation beyond the limits of the TTR intronic boundaries imposed by the earlier intragenic haplotype analyses. The identification of a single microsatellite haplotype (3-2) linked to V30M in Swedish patients (versus six haplotypes in noncarrier chromosomes) is supportive of the earlier studies, assigning a single intragenic haplotype to the Swedes. In contrast, the association of V30M with two microsatellite haplotypes (3-2 and 3-1) in the Portuguese is not in agreement with the earlier data for this population; however, the 
Table 10 Composite of the haplotype results obtained in the studies presented here: possible correspondence between the haplotypes based in TTR flanking SNPs and microsatellites (this study) and the intragenic haplotypes described elsewhere

\begin{tabular}{|c|c|c|c|c|c|c|}
\hline & Flanking SNP haplotypes & Origin & $(C A)_{n}$ allele & Microsatellite haplotypes & Intragenic haplotypes & Origin \\
\hline ii & G-T-C & Independent & 9 & $\begin{array}{r}3-1(0.46) \\
3-2(0.23) \\
3-3(0.15) \\
+2(0.15)\end{array}$ & III & Independent \\
\hline iii & A-T-C & Recomb. $\mathrm{i} \times \mathrm{ii}$ & $?$ & $?$ & I or III & \\
\hline iv & G-T-T & Recomb. $\mathrm{i} \times \mathrm{ii}$ & $?$ & $?$ & III (V ?) & Independent \\
\hline$v$ & A-T-T & Recomb. $\mathrm{i} \times$ iv & 10 & $\begin{array}{l}6-2 \\
3-3\end{array}$ & I or III (IV ?) & Recomb. I $\times \mathrm{V}$ \\
\hline
\end{tabular}

Frequencies of the most common microsatellite haplotypes are shown in parenthesis.

The haplotypes that have been combined $(+4 ;+2)$ do not include haplotypes $6-2,3-3$, or $6-1$, as observed for A-T-T and G-C-T haplotypes. Recomb: arising from recombination of.

Entries in italics represent haplotypes not arising from recombination between known haplotypes.

former haplotype could be derived from the latter by recombination rather than by a new mutation arising in association with haplotype 3-1. Two lines of evidence support this notion. The haplotype frequencies among FAP patients and the general population (19.2 and 21.3\%, respectively) are very similar. Furthermore, the SNP haplotype analysis revealed a single haplotype (A-C-T) (with a sole exception) bearing the V30M mutation. The extended analyses may be more conclusive than those carried out previously, in that they consider the background variation in a broader interval around and in the vicinity of TTR. The identification of 13 microsatellite and six SNP haplotypes in Portuguese subjects, which, based on the total number of chromosomes examined, are significantly different from the six microsatellite and four SNP haplotypes in the Swedes illustrates the genetic diversity between these populations and is consistent with the older age of the Portuguese population. ${ }^{25}$ It suggests, from a genetic standpoint, that the Portuguese could have introduced the V30M mutation to Sweden with a common ancestor explaining the high frequency of a particular TTR flanking and intragenic haplotype linked to V30M in both countries.

\section{Acknowledgements}

We thank Dr Rosário Santos from the Instituto de Genética Médica Jacinto Magalhães for the Portuguese control DNA samples, Paul Moreira for his expertise in DNA diagnosis of the V3OM mutation, and Isabel Friães and Laurinda Teixeira for their assistance in collecting blood samples. We also appreciated the review of the manuscript by
Drs Jim Koziol and Ernest Beutler of the Department of Molecular and Experimental Medicine at TSRI, and acknowledge the statistical assistance of Dr Chris Amos, MD Anderson Hospital, Houston, TX. Miguel Soares was recipient of a fellowship (PRAXIS XXI, BD/11564/ 97) from Fundação para a Ciência e Tecnologia, Portugal. Grants from the NIH (R01 AG19259 to JB), the Fundação para Ciência e Tecnologia (to MJS) and the Swedish Medical Research Council (Project 0945 to GH) supported this work.

\section{References}

1 Andrade C: A peculiar form of peripheral neuropathy. Familial atypical generalized amyloidosis with special involvement of the peripheral nerves. Brain 1952; 75: 408-427.

2 Sousa A, Coelho T, Lobato L, Sequeiros J: Genetic epidemiology of familial amyloidotic polyneuropathy (FAP)-type I (FAP-MET30). in Kyle R (ed): Amyloid and amyloidosis. New York and London: Parthenon; 1995, pp 209-211.

3 Coutinho P, Silva AM, Lima JL, Barbosa AR: Forty years of experience with type I amyloid neuropathy. Review of cases. in Glenner GG, Costa PP and Freitas AF (eds): Amyloid and amyloidosis. Amsterdam: Plenum Press; 1980, pp 88-98.

4 Coelho T, Sousa A, Lourenco E, Ramalheira J: A study of 159 Portuguese patients with familial amyloidotic polyneuropathy (FAP) whose parents were both unaffected. J Med Genet 1994; 31: 293-299.

5 Sousa A, Coelho T, Lobato L, Sequeiros J: Anticipation of age-atonset in Portuguese patients with familial amyloid polyneuropathy-type I (FAP-MET30). in Kyle $\mathrm{R}$ et al (eds): Amyloid and amyloidosis. New York and London: Parthenon; 1999, pp 209-211.

6 Soares M, Buxbaum J, Sirugo G et al: Genetic anticipation in Portuguese kindreds with familial amyloidotic polyneuropathy is unlikely to be caused by triplet repeat expansions. Hum Genet 1999; 104: 480-485.

7 Andersson R: Familial amyloidosis with polyneuropathy. A clinical study based on patients living in Northern Sweden. Acta Med Scand 1976; 590: 1-64. 
8 Sousa A, Andersson R, Drugge U, Holmgren G, Sandgren O: Familial amyloidotic polyneuropathy in Sweden: geographical distribution, age of onset, and prevalence. Hum Heredity 1993; 43: $288-294$

9 Tashima K, Ando Y, Tanaka Y, Uchino M, Ando M: Change in the age of onset in patients with familial amyloidotic polyneuropathy type I. Intern Med 1995; 34: 748-750.

10 Yoshioka K, Furuya H, Sasaki H, Saraiva MJM, Costa PP, Sakaki Y: Haplotype analysis of familial amyloidotic polyneuropathy. Evidence for multiple origins of the Val-Met mutation most common to the disease. Hum Genet 1989; 82: 9-13.

11 Ii S, Sommer SS: The high frequency of TTR $\mathrm{M}^{30}$ in familial amyloidotic polyneuropathy is not due to a founder effect. Hum Mol Genet 1993; 2: 1303-1305.

12 Waits RP, Uemichi T, Benson MD: Haplotype analysis of the transthyretin gene: evidence for multiple recurrence of the Met30 mutation in the Caucasian population. Amyloid Int J Exp Clin Investig 1995; 2: 114-118.

13 Baker D, Schafer M, White R: Restriction sites containing CpG show a higher frequency of polymorphism in human DNA. Cell 1984; 36: 131-138.

14 Cooper DN, Youssoufian H: The CpG dinucleotide and human genetic disease. Hum Genet 1988; 78: 151-155.

15 Almeida MR, Alves IL, Sakaki Y, Costa PP, Saraiva MJM: Prenatal diagnosis of familial amyloidotic polyneuropathy: evidence for an early expression of the associated transthyretin methionine 30. Hum Genet 1990; 85: 623-626.

16 Sakaki Y, Yoshioka K, Tanahashi H, Furuya H, Sasaki H: Human transthyretin (prealbumin) gene and molecular genetics of familial amyloidotic polyneuropathy. Mol Biol Med 1989; 6: $161-168$.

17 Clark AG: Inference of haplotypes from PCR-amplified samples of diploid populations. Mol Biol Evol 1990; 7: 111-122.

18 Freeman G, Halton JH: Note on an exact treatment of contingency, goodness of fit and other problems of significance. Biometrika 1951; 38: 141-149.

19 Whitehead AS, Skinner M, Bruns GAP et al: Cloning of human prealbumin complementary DNA. Localization of the gene to chromosome 18 and detection of a variant prealbumin allele in a family with familial amyloid polyneuropathy. Mol Biol Med 1984; 2: $411-423$

20 Alves IL, Jacobson DR, Torres MF, Holmgren G, Buxbaum J, Saraiva MJ: Transthyretin Ser6 as a neutral polymorphism in familial amyloidotic polyneuropathy. Amyloid Int J Exp Clin Investig 1996; 3: 242-244.

21 Cooper DN, Smith BA, Cooke HJ, Niemann S, Schmidtke J: An estimate of unique DNA sequence heterozygozity in the human genome. Hum Genet 1985; 69: 201-205.

22 Li WH, Sadler LA: Low nucleotide diversity in man. Genetics 1991; 129: $513-523$.

23 Almeida MR, Aytama-Oishi N, Sakaki Y et al: Haplotype analysis of common transthyretin mutations. Hum Genet 1995; 96: $350-354$.

24 Plante-Bordeneuve V, Lalu T, Misrahi M et al: Genotypicphenotypic variations in a series of 65 patients with familial amyloid polyneuropathy. Neurology 1998; 51: 708-714.

25 Cavalli-Sforza L, Menozzi P, Plazza A: The History and Geography of Human Genes. Princeton University Press, Princeton, New Jersey, 1994. 